\title{
Fatal eller letal?
}

Både fatal og letal betyr noe som fører til døden. Fatal er mest brukt, men letal er mest presist.

Ordet «fatal» kan bety to ting: «uheldig, skjebnesvanger» eller «som fører til døden». Den første betydningen tilhører dagligspråket, den andre er medisinsk (1). Når man i dagligspråket snakker om fatale feil eller fatale misforståelser, er det uheldige hendelser man tenker på - resultatet er som regel ikke så ille. Hvis medisinere snakker om det samme, er det katastrofer.

Fatal kommer fra latin fatalis «skjebnesvanger», som er avledet av fatum «skjebne» (2). Vi kjenner det igjen på engelsk fate (skjebne). Fatalisme er troen på at alt som skjer, er forutbestemt og uavvendelig (3). Men for moderne mennesker ligger det ingen tanker om skjebne bak ordet fatal. Det dreier seg rett og slett om ubehagelige eller ulykkelige ting (4). Det gjelder også på engelsk (5). Der snakker man f.eks. om «fatal flaws» i manuskripter med grunnleggende feil.

Valøren av ordet fatal er imidlertid ikke entydig. Enkelte mener at det oftest handler om ting med katastrofale følger (2), og da flyter betydningene $\mathrm{i}$ allmennspråket $\mathrm{og}$ medisinen over i hverandre. Men slik trenger det ikke være. Da Henrik Ibsen (1828-1906) ble rammet av hjerneslag, omtalte han det som fatalt, uten tanker om at det skulle ende med døden: «Med min dårlige fod går det nu stadig fremad,» skrev han, «og jeg håber nu snart at være helt færdig med den fatale historie» (6). Ibsen var godt kjent med ordet. I En folkefiende lar han byfogden si: «Det fataleste er, at vi blir nødt til at lukke badet et par års tid» (7).

Et annet fatalt eksempel er romansen mellom den unge dansk-norske dronning Caroline Mathilde (1751-75) og kongens livlege, Johann Friedrich Struensee (1737-72) (2). Hun begikk sitt livs fatale feiltrinn da hun forelsket seg i ham. Det medførte ikke døden for henne, men det kostet livlegen livet, så for ham kan man si at det var fatalt også i medisinsk forstand.

\section{Letal}

Letal brukes omtrent kun i medisinske sammenhenger. Det betyr «dødelig» eller «som fører til døden». Det stammer fra latin letum, som rett og slett betyr død (8). Hvis man snakker om letal dose av et stoff, menes den dosen som vanligvis fremkaller døden. Avledningen letalitet er en del brukt innen epidemiologien som et mål på dødelighet. Det betegner andelen av dem som har fått en sykdom som dør av den i løpet av en gitt tidsperiode.

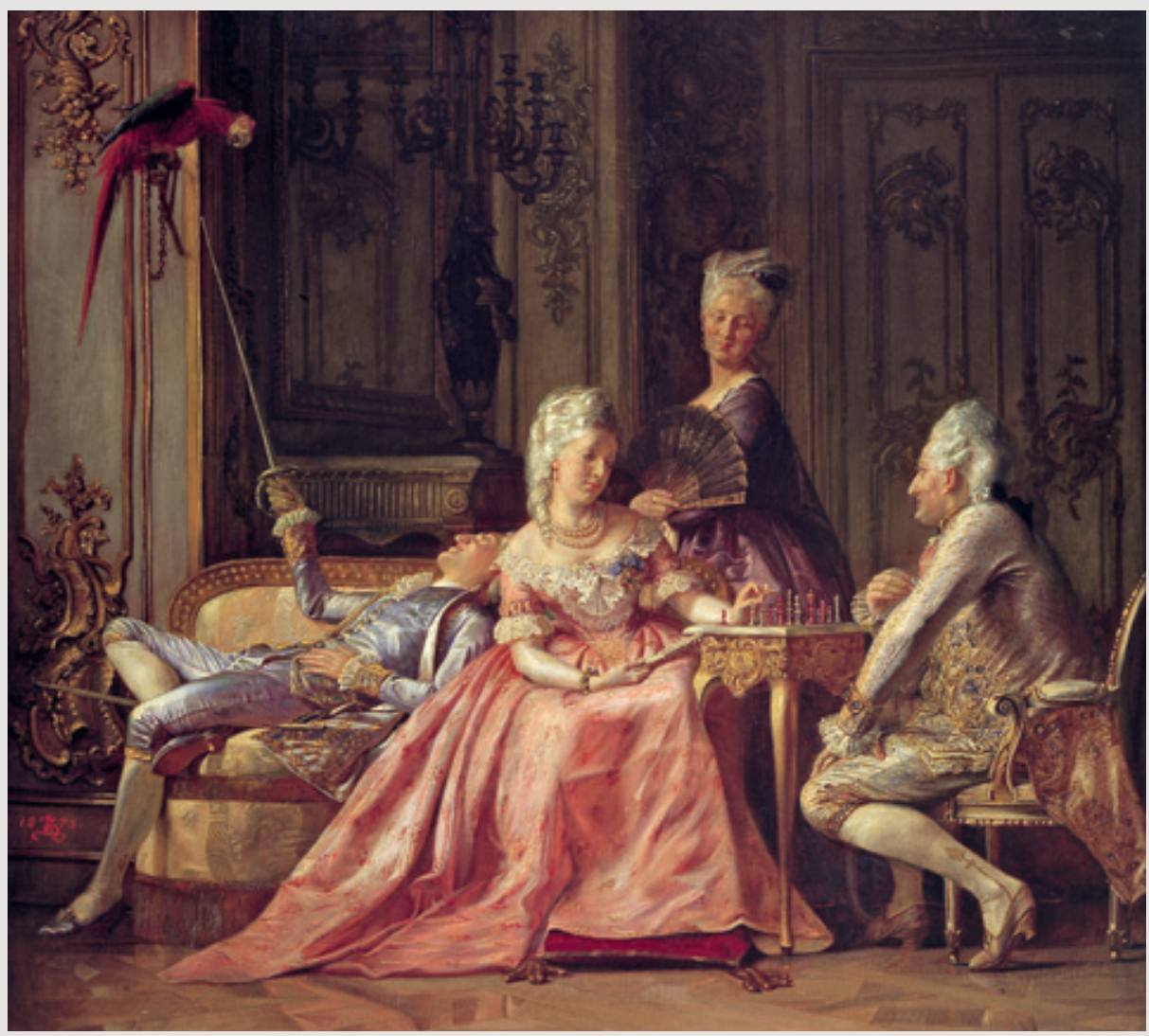

Dronning Caroline Mathilde og hennes elsker, livlege Struensee, spiller sjakk, den sinnssyke kong Christian driller en papegøye og hoffdamen følger vaktsomt med. Scene fra Christian VII's Hof (1873) av Kristian Zahtmann (1843-1917). Olje på lerret. 92 x 83 cm. Den Hirschsprungske Samling

Letal er altså mer presist enn fatal. Likevel er fatal langt hyppigere brukt på norsk, også i medisinsk sammenheng. I Tidsskriftet er fatal registrert 245 ganger, letal bare 29 (15.8. 2010).

Vi har ellers merket oss at letal ofte refererer til midlet, f.eks. en letal dose, mens fatal ofte dreier seg om utfallet, f.eks. sykdom eller død.

\section{Konklusjon}

Ettersom ordet fatal har to betydninger, blir budskapet ofte uklart. Mener man at noe er dødelig eller bare uheldig? Ord med flere betydninger finnes det mange av. Det er til å leve med. Det er altså ikke fatalt.

\section{Erlend Hem}

erlend.hem@medisin.uio.no

Geir W. Jacobsen

Tidsskriftet

Erlend Hem (f. 1970) er dr.med. og medisinsk redaktør i Tidsskriftet.
Geir Jacobsen (f. 1945) er professor ved Institutt for samfunnsmedisin, Norges teknisknaturvitenskapelige universitet og medisinsk redaktøri Tidsskriftet.

\section{Litteratur}

1. Fatal. I: Bokmålsordboka og Nynorskordboka. www.dokpro.uio.no/perl/ordboksoek/ordbok. cgi?OPP=fatal\% (15.8.2010)

2. Fatal. I: Den Danske Ordbog. Det Danske Sprogog Litteraturselskab. http://ordnet.dk/ddo/ ordbog?query=fatal (15.8.2010).

3. Fatalisme. I: Store Norske Leksikon http://snl.no/fatalisme (15.8.2010)

4. Fatal. I: Norsk ordbok. http://ordnett.no/ordbok. html? search=fatal\&search_type=\&publications= 23 (15.8.2010).

5. Fatal. I: Oxford English Dictionary. http:// dictionary.oed.com/cgi/entry/50082635 (15.8.2010).

6. Frich JC. Hem E. Den fatale historie - Ibsens helse $i$ hans siste år. Tidsskr Nor Lægeforen 2006; 126 : 1497-501.

7. Ibsen H. En folkefiende. Skuespil i fem akter (1882). Henrik Ibsens skrifter. Universitetet i Oslo, 2005: 78. http://ibsen.net/xml/11124385/EFFU.pdf (15.3.2011)

8. Lethal. I: Oxford English Dictionary. http:// dictionary.oed.com/cgi/entry/50132146 (15.8.2010). 